\title{
Lipid and lipoprotein responses of dyslipidemic patients to exclusive nutritional counseling by gender and age
}

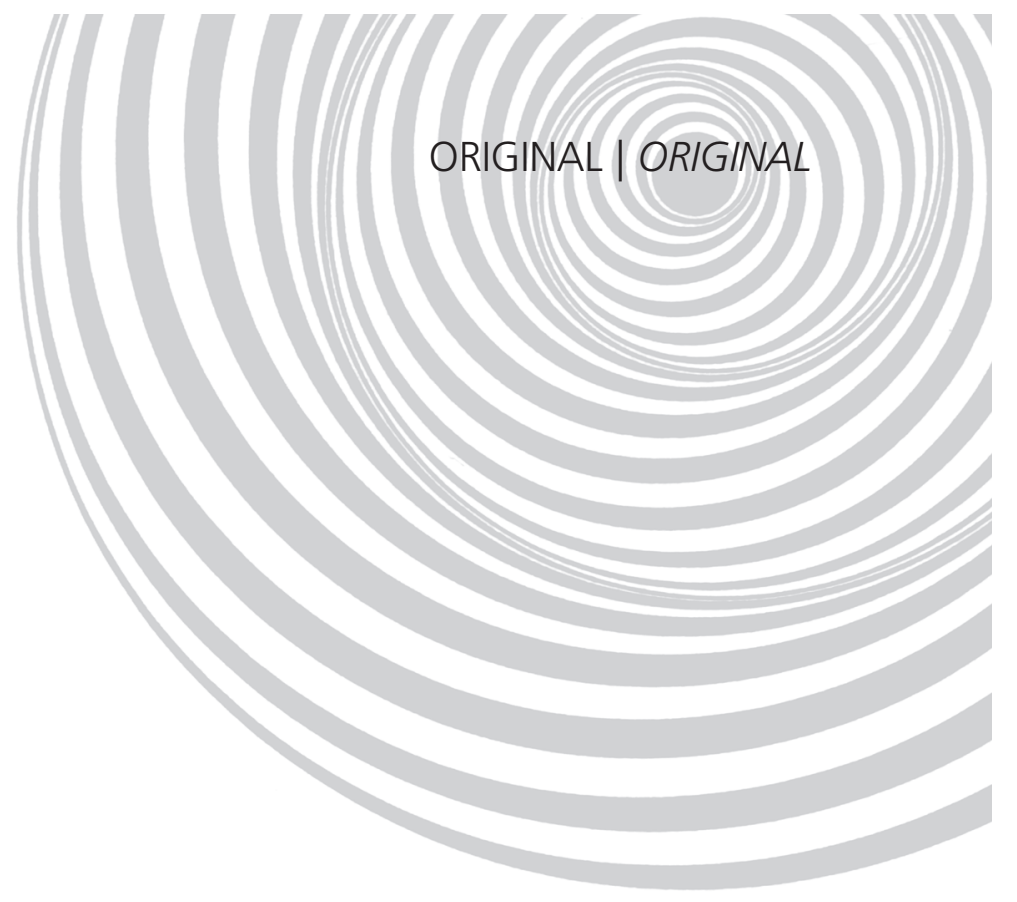

\author{
Resposta nos lípides e nas lipoproteínas séricas \\ ao aconselhamento nutricional exclusivo \\ em indivíduos dislipidêmicos \\ segundo o sexo e a idade
}

\author{
Harumi KINCHOKU ${ }^{1}$ \\ Vera Sylvia CASTANHO2 \\ Mirian Regina Gardin DANELON ${ }^{1}$ \\ Eliana Cotta de FARIA ${ }^{3}$
}

\section{A B S T R A C T}

\section{Objective}

The aim of the present study was to evaluate the plasma lipid responses of dyslipidemic patients to nutritional counseling according to gender and age.

\section{Methods}

One-hundred and twenty nine dyslipidemic subjects comprised the study, 56 men and 73 women, aged 20 to 73 years, treated at the Dyslipidemia Outpatient Clinic of the Universidade Estadual de Campinas Clinic Hospital. The inclusion criteria established that no lipid-lowering medication had been used in the 30 days prior to and during the nutritional counseling. Blood samples were collected in the morning after a 12 hour fast. The participants were divided into groups according to gender and age (age $<60$ and $\geq 60$ years). The hypercholesterolemic patients were instructed to restrict saturated fats $(<7 \%)$ and cholesterol $(<200 \mathrm{mg} /$ day $)$. Those presenting with high triglyceride levels $(>300 \mathrm{mg} / \mathrm{dL}$ ) were asked to consume a low fat diet. Those with mixed hyperlipidemia were instructed to do both. Statistical analyses included the Wilcoxon, Mann-Whitney, Chi-square and Fisher's exact tests and Analysis of Covariance.

\footnotetext{
1 Universidade Estadual de Campinas, Hospital de Clínicas, Divisão de Nutrição e Dietética. R. Vital Brasil, 251, Cidade Universitária Zeferino Vaz, Barão Geraldo, 13083-888, Campinas, SP, Brasil. Correspondence to/Correspondência para: H KINCHOKU. E-mail: <harumi@hc.unicamp.br>.

2 Universidade Estadual de Campinas, Hospital de Clínicas, Divisão de Patologia Clínica. Campinas, SP, Brasil.

${ }^{3}$ Universidade Estadual de Campinas, Faculdade de Ciências Médicas, Departamento de Patologia Clínica. Campinas, SP, Brasil.
} 
216 | H KINCHOKU et al.

\section{Results}

After nutritional counseling, total cholesterol and triglycerides decreased by $16 \%$ and $36 \%$ in males, and by $12 \%$ and $26 \%$ in females, respectively, and Low Density Lipoprotein-cholesterol decreased by $12 \%$ in females. Only triglycerides decrease significantly. In the mixed hyperlipidemia group, the male and female triglyceride (-44\% and -29\%), Low Density Lipoprotein-cholesterol (+12\% and -15\%) and High Density Lipoprotein-cholesterol $(+7 \%$ and $-3 \%)$ levels differed significantly. Between the age groups, only triglyceride levels differed significantly, with adults experiencing the highest reductions (33\%).

\section{Conclusion}

Nutritional counseling effectively lowered plasma lipid and lipoprotein levels, reinforcing the benefits of dietary interventions for the treatment of dyslipidemia.

Indexing terms: Age groups. Diet. Dyslipidemias. Gender. Nutritional counseling.

\section{R E S U M O}

\section{Objetivo}

Avaliar a resposta do perfil lipídico e das lipoproteínas plasmáticas ao aconselhamento nutricional em individuos dislipidêmicos analisando as respostas entre os sexos e as faixas etárias.

\section{Métodos}

Participaram do estudo 129 indivíduos dislipidêmicos, 56 homens e 73 mulheres, de 20 a 73 anos, atendidos no Ambulatório de Dislipidemias do Hospital de Clínicas da Universidade Estadual de Campinas. Os critérios de exclusão foram: uso de medicação hipolipemiante no mínimo 30 dias antes da entrevista inicial elou durante o acompanhamento. Os participantes foram divididos em grupos segundo sexo e faixa etária ( $\geq 60$ ou $<60$ anos). Orientou-se restrição de gorduras saturadas $(<7 \%)$ e colesterol ( $<200 \mathrm{mg} / \mathrm{dia})$, além das gorduras totais $(<20 \%)$ para valores de triglicérides $>300 \mathrm{mg} / \mathrm{dL}$, nos hipercolesterolêmicos. Na hiperlipidemia mista utilizou-se ambas orientações.

\section{Resultados}

No sexo masculino, a redução de colesterol total e triglicerides foi de $16 \%$ e $36 \%$ respectivamente; no feminino 12\%, 26\%, e de 12\% para a Lipoproteína de Baixa Densidade, com significância apenas para o triglicerides. $\mathrm{Na}$ hiperlipidemia mista, as diferenças entre os sexos foram significativas para triglicerides (-44\% e -29\%), Lipoproteína de Baixa Densidade (+12\% e -15\%) e Lipoproteína de Alta Densidade +7\% e -3\%), respectivamente. Entre as faixas etárias, a diferença foi significativa apenas para o triglicerides; os adultos apresentaram maiores reduções (33\%).

\section{Conclusão}

O aconselhamento nutricional mostrou-se efetivo na redução de lípides e lipoproteínas plasmáticos, reforçando os benefícios das intervenções dietéticas no tratamento das dislipidemias.

Termos de indexação: Grupos etários. Dieta. Dislipidemias. Sexo. Aconselhamento nutricional.

\section{NTRODUCTION}

Cardiovascular Disease (CVD) is the leading cause of mortality in men and women in the United States ${ }^{1}$ and the leading cause of disability and premature death worldwide ${ }^{2}$. In Brazil, it is the main cause of death and the second cause of hospitalization ${ }^{3}$.

In addition to the risk factors for Coronary Heart Disease (CHD), namely age, hypertension, diabetes, smoking, low High Density Lipoprotein- cholesterol (HDL-c) level (<40mg/dL), and high Low Density Lipoprotein-cholesterol (LDL-c) level (>160mg/dL), being male also increases the risk of $\mathrm{CHD}^{4}$.

The strongest dietary determinants of high LDL-C are saturated fat and trans fat intakes, and to a lesser extent, cholesterol intake and excess body weight ${ }^{5}$.

Excessive carbohydrate intake and alcohol can cause or exacerbate hypertriglyceridemia 
because of high hepatic synthesis of triglycerides, production of Very Low-Density Lipoproteincholesterol (VLDL-C), and reduction of triglyceriderich lipoprotein catabolism ${ }^{6}$.

The IV Brazilian Guidelines on Dyslipidemia and Prevention of Atherosclerosis (Diretriz Brasileira Sobre Dislipidemias e Prevenção da Aterosclerose) $^{7}$ and the National Cholesterol Education Program ${ }^{4}$ (NCEP) recommend that individuals with high cholesterol levels should limit the saturated fat intake to less than $7 \%$ of the total energy intake and cholesterol intake to less than 200mg per day; individuals with high triglyceride levels should limit carbohydrate intake to less than $60 \%$ of the total energy intake, avoid simple sugars such as sucrose, limit alcohol intake and reduce total fat intake ${ }^{6}$.

A number of factors, such as age, gender, genetic makeup, baseline serum cholesterol level and habitual diet, alone or in combination, can impact study outcomes and strongly affect study conclusion $^{8}$.

There are a few studies in the literature that assess how gender affects the variation of serum lipid levels in response to dietary inverventions ${ }^{9}$. Some studies show that men experience a greater reduction in LDL-C in response to diet ${ }^{10,11}$, whereas others did not find any gender-related difference ${ }^{12}$.

The objective of the present study was to evaluate how the plasma lipid and lipoprotein levels of hyperlipidemic patients respond to diet and analyze the response by gender and age $(<60$ and $\geq 60$ years).

\section{METHODS}

The study included 129 individuals, 56 males and 73 females, aged 20 to 73 years treated at the Dyslipidemia Outpatient Clinic of the Universidade Estadual de Campinas (Unicamp) Clinic Hospital. They were referred to the Nutrition Service for follow-up and advice on better lifestyle habits.
The exclusion criteria were the use of lipidlowering medications in the 30 days prior to and during the nutritional counseling. Other medications were allowed.

Blood samples were collected in the morning after an overnight fast of at least 12 hours. The participants were also instructed to abstain from doing physical activities during that period. The biochemical analyses were done by an automated system using enzymatic colorimetric methods, and LDL-C was estimated by Friedewald's ${ }^{13}$ equation when Triglycerides (TG) level was $<400 \mathrm{mg} / \mathrm{dL}$. All biochemical analyses were done at the biochemistry division of the Clinic Hospital. Non HDL-c (NHDL-c) was given by the formula: $\mathrm{C}-\mathrm{HDL}-\mathrm{C}^{4}$.

The cutoffs for the diagnosis of dyslipidemias were those provided by the IV Brazilian Guidelines on Dyslipidemia and Prevention of Atherosclerosis ${ }^{7}$, which are: isolated hypercholesterolemia (C>200mg/dL and $\mathrm{TG}<150 \mathrm{mg} / \mathrm{dL}$ ); isolated hypertriglyceridemia $(C<200 \mathrm{mg} / \mathrm{dL}$ and $\mathrm{TG}>$ $150 \mathrm{mg} / \mathrm{dL}$ ); mixed hyperlipidemia ( $C>200 \mathrm{mg} / \mathrm{dL}$ and $T G>150 \mathrm{mg} / \mathrm{dL}$ ); and hypoalphalipoproteinemia ( $\mathrm{HDL}-\mathrm{C}<40 \mathrm{mg} / \mathrm{dL}$ ) found in the 3 types of dyslipidemias.

The risk factors for Coronary Artery Disease (CAD), in addition to high LDL-C, were hypertension (blood pressure $\geq 140: 90 \mathrm{mmHg}$ ), diabetes (fasting blood glucose $\geq 126 \mathrm{mg} / \mathrm{dL}$ ), smoking daily regardless of amount, early-onset atherosclerosis in first-degree male relatives $<55$ years and first-degree female relatives $<65$ years, and ages $\geq 45$ in men and $\geq 55$ in women 4 .

Body Mass Index (BMI) was used for determining the nutritional status of the participants and Waist Circumference (WC) for identifying their risk of metabolic syndrome ${ }^{14,15}$.

The participants were grouped by gender (56 men and 73 women) and age (106 adults aged $<60$ years and 23 elderly aged $\geq 60$ years). The nutritional follow-up by gender lasted: 3 months (10 men and 14 women), 6 months ( 29 men and 33 women), 12 months (17 men and 26 women); 
and by age group, 3 months (19 adults and 5 elderly), 6 months (52 adults and 10 elderly) and 12 months (35 adults and 8 elderly).

Habitual diet was determined by a 24 hour recall and by collecting information about foods and preparations consumed regularly 16,17 .

Energy (kcal), macronutrient (\%), cholesterol (mg/day), saturated fat (\%), monounsaturated fat (\%) and polyunsaturated fat (\%) intakes were estimated by the Nutrition Support Program of the Universidade Federal de São Paulo ${ }^{18}$.

Dietary counseling was provided after quantitative and qualitative dietary assessment, which consisted of adjusting the intakes of energy, total fat, especially saturated fat ( $\leq 7 \%$ of total calories), cholesterol ( $\leq 200 \mathrm{mg} /$ day), fiber and other nutrients according to the type of dyslipidemia and presence of other diseases. The participants were also instructed about the selection, preparation and recommended amounts of food substitutes.

Individuals with high triglyceride levels were advised to limit the intake of simple carbohydrates and alcoholic beverages. If $\mathrm{TG}>300 \mathrm{mg} / \mathrm{dL}$, they were also asked to reduce total fat intake ( $<20 \%$ of total calories). Individuals with mixed hyperlipidemia were instructed to follow both recommendations ${ }^{7}$.

Dietary recommendations were personalized according to the participant's needs. Overweight participants $(80 \%$ of the total) were given a low-energy diet and instructed to gradually decrease energy intake ${ }^{19}$.

A follow-up interview was done to assess adherence to nutritional counseling. The participants were asked about their adherence to the prescribed diet, difficulties and doubts. Serum lipid and lipoprotein levels, weight and BMI were also measured, comparing the new results with the baseline results.

Diet adequacy was determined by biochemical tests, anthropometric parameters and adherence to nutritional counseling, emphasizing the importance of following the diet plan.
Information about the participants' progress was recorded in their medical records in the institution's database.

There were at least 2 and at most 3 clinical and nutritional follow-ups. The first follow-up occurred from 30 to 90 days after the nutritional intervention. The frequency of and interval between the other follow-up visits depended on the participants' response to nutritional counseling and severity of dyslipidemia.

The study was approved by the Research Ethics Committee of Universidade Estadual de Campinas, School of Medicine under protocol number 647/2005.

\section{Statistical Analysis}

The statistical analyses were done by the software Statistical Analysis System (SAS) for Windows, version 6.12 and included the Wilcoxon, Chi-square, Mann-Whitney and Fischer's exact tests, and Analysis of Covariance (Ancova). The significance level was set at 5\%, with borderline values of $p>5$ and $<10 \%$.

\section{RESULTS}

Table 1 shows the clinical, anthropometric, and lipid and lipoprotein profiles of the participants.

Women's mean age was higher than that of men. On the other hand, men and adults were heavier, and men had higher waist circumferences. The baseline lipid and lipoprotein levels of the participants were very high. Hypertension was more common in women and in the elderly. Men and adults had higher energy intakes, and women had higher saturated fat intake. The participants also presented high protein, fat and cholesterol intakes (Table 2).

After nutritional counseling, participants' C, TG, LDL-C and non-HDL-C decreased by $14 \%$, $30 \%, 5 \%$ and $17 \%$, respectively (Figure 1 ).

When the results were analyzed according to type of dyslipidemia, the TG levels of individuals 
with isolated hypertriglyceridemia decreased significantly, by $45 \%$ ( $p=0.04)$.

The decrease in lipid and lipoprotein levels in response to the diet, according to gender, was: $16 \%$ for $C(p<0.001), 36 \%$ for TG $(p<0.001)$ and $21 \%$ for non-HDL-c $(p<0.001)$ for men and $12 \%$ for $C(p<0.001), 26 \%$ for TG $(p<0.001), 12 \%$ LDL$c(p<0.001)$ and $14 \%$ for NHDL-c $(p<0.001)$ for women. The decrease in the TG levels of men and women differed significantly.
Men and women with hypercholesterolemia presented similar decreases in C and LDL-C in response to diet (15\% and $20 \%$, respectively) (Figure 2A).

In response to diet, the males in the mixed hyperlipidemia group saw reductions of $18 \%$ in C, $23 \%$ in NHDL-C and $44 \%$ in TG and an increase of $7 \%$ in $\mathrm{HDL}-\mathrm{C}$; females saw reductions of $13 \%$ in C, $14 \%$ in non-HDL-C, $29 \%$ in TG and $3 \%$ in $\mathrm{HDL}-\mathrm{C}$, in addition to a $15 \%$ reduction in LDL-C.

Table 1. Clinical, anthropometric and biochemical characteristics of the participants

\begin{tabular}{|c|c|c|c|c|c|}
\hline Parameters & Total (129) & Men $(n=56)$ & Women $(n=73)$ & Adults $(n=106)$ & Elderly $(n=23)$ \\
\hline Age (years) & $\begin{array}{l}52 \pm 11 \\
(20-73)\end{array}$ & $\begin{array}{c}44 \pm 9 \\
(22-65)\end{array}$ & $\begin{array}{l}52 \pm 11^{*} \\
(20-73)\end{array}$ & $\begin{array}{c}45 \pm 9 \\
(20-60)\end{array}$ & $\begin{array}{c}64 \pm 4 \\
(61-73)\end{array}$ \\
\hline Weight (kg) & $\begin{array}{l}74 \pm 13 \\
(44-136)\end{array}$ & $\begin{array}{c}84 \pm 14 \\
(58-123)\end{array}$ & $\begin{array}{l}69 \pm 13^{*} \\
(42-134)\end{array}$ & $\begin{array}{c}77 \pm 15 \\
(46-136)\end{array}$ & $\begin{array}{l}69 \pm 12^{\dagger} \\
(44-105)\end{array}$ \\
\hline BMI (W/H2) & $\begin{array}{c}29 \pm 5 \\
(16-51)\end{array}$ & $\begin{array}{c}29 \pm 5 \\
(21-42)\end{array}$ & $\begin{array}{c}28 \pm 5 \\
(16-51)\end{array}$ & $\begin{array}{c}29 \pm 5 \\
(21-51)\end{array}$ & $\begin{array}{c}28 \pm 4 \\
(16-35)\end{array}$ \\
\hline Waist circumference $(\mathrm{cm})$ & $\begin{array}{c}92 \pm 13 \\
(61-145)\end{array}$ & $\begin{array}{c}97 \pm 12 \\
(72-123)\end{array}$ & $\begin{array}{l}87 \pm 12^{*} \\
(61-145)\end{array}$ & $\begin{array}{c}92 \pm 13 \\
(70-145)\end{array}$ & $\begin{array}{c}90 \pm 13 \\
(61-118)\end{array}$ \\
\hline$C(\mathrm{mg} / \mathrm{dL})$ & $\begin{array}{c}263 \pm 50 \\
(126-429)\end{array}$ & $\begin{array}{c}260 \pm 53 \\
(126-413)\end{array}$ & $\begin{array}{c}266 \pm 48 \\
(157-429)\end{array}$ & $\begin{array}{c}261 \pm 49 \\
(126-413)\end{array}$ & $\begin{array}{c}275 \pm 54 \\
(164-429)\end{array}$ \\
\hline LDL-c (mg/dL) & $\begin{array}{l}163 \pm 61 \\
(27-356)\end{array}$ & $\begin{array}{l}140 \pm 61 \\
(35-254)\end{array}$ & $\begin{array}{l}180 \pm 55 \\
(27-356)\end{array}$ & $\begin{array}{l}157 \pm 61 \\
(27-314)\end{array}$ & $\begin{array}{l}199 \pm 55 \\
(95-356)\end{array}$ \\
\hline HDL-c (mg/dL) & $\begin{array}{c}47 \pm 17 \\
(16-112)\end{array}$ & $\begin{array}{c}42 \pm 17 \\
(16-112)\end{array}$ & $\begin{array}{l}51 \pm 15 \\
(22-91)\end{array}$ & $\begin{array}{c}46 \pm 17 \\
(16-112)\end{array}$ & $\begin{array}{l}53 \pm 15 \\
(22-78)\end{array}$ \\
\hline NHDL-c (mg/dL) & $\begin{array}{c}219 \pm 48 \\
(102-381)\end{array}$ & $\begin{array}{c}221 \pm 52 \\
(102-381)\end{array}$ & $\begin{array}{c}218 \pm 45 \\
(124-375)\end{array}$ & $\begin{array}{l}218 \pm 47 \\
(102-81)\end{array}$ & $\begin{array}{c}224 \pm 52 \\
(136-375)\end{array}$ \\
\hline VLDL-c (mg/dL) & $\begin{array}{l}41 \pm 19 \\
(9-79)\end{array}$ & $\begin{array}{l}43 \pm 23 \\
(9-78)\end{array}$ & $\begin{array}{l}40 \pm 17 \\
(15-71)\end{array}$ & $\begin{array}{l}42 \pm 19 \\
(9-78)\end{array}$ & $\begin{array}{l}38 \pm 18 \\
(15-61)\end{array}$ \\
\hline $\mathrm{TG}(\mathrm{mg} / \mathrm{dL})$ & $\begin{array}{l}364 \pm 308 \\
(46-1837)\end{array}$ & $\begin{array}{l}483 \pm 403 \\
(46-1837)\end{array}$ & $\begin{array}{l}273 \pm 159 \\
(72-795)\end{array}$ & $\begin{array}{l}388 \pm 328 \\
(46-1837)\end{array}$ & $\begin{array}{c}253 \pm 154 \\
(72-522)\end{array}$ \\
\hline \multicolumn{6}{|l|}{ Frequency (\%) } \\
\hline Hypercholesterolemia & 25 & 21 & 27 & 23 & 30 \\
\hline Hypertriglyceridemia & 11 & 11 & 11 & 22 & 18 \\
\hline Mixed hyperlipidemia & $63^{\ddagger}$ & 68 & 60 & 54 & 52 \\
\hline Hypoalphalipoproteinemia & 38 & $50^{\S}$ & 28 & $42^{\pi}$ & 18 \\
\hline Hypertension & 39 & 21 & $52^{\prime \prime}$ & 32 & $69^{\pi}$ \\
\hline Diabetes Mellitus & 11 & 16 & 8 & 10 & 17 \\
\hline CAD family $>55 \mathrm{M}>65 \mathrm{~W}$ & 9 & 10 & 8 & 11 & \\
\hline Age $\geq 45 y \mathrm{~W} \geq 55 \mathrm{y} M$ & 47 & 46 & 48 & 35 & 100 \\
\hline Smoking & 13 & 19 & 8 & 15 & 4 \\
\hline
\end{tabular}

Note: $p=$ Mann Whitney adjusted for age, weight and Waist circumference e to gender and weight-for-age (Ancova): ${ }^{*} p<0.001 \mathrm{for}$ gender, and ${ }^{\dagger} p=0.018$ for age, $p=$ Chi-square; ${ }^{\ddagger} p<0.001$ all the groups; ${ }^{\S} p=0.014 ; "$ p $p<0.001$ and for gender; ${ }^{\text {I }} p<0.001$ for age.

Adults (<60 years) and elderly ( $\geq 60$ years). Values expressed as means \pm Standard Deviation (SD), frequency (\%), and minimum and maximum ( ) for each group. M: Men; W: Women; C: Cholesterol; LDL-C: Low Density Lipoprotein-cholesterol; HDL-c: High Density Lipoprotein-cholesterol; NHDL-c: Non-HDL-C; VLDL-c: Very Low Density Lipoprotein-cholesterol; TG: Triglycerides; CAD: Coronary Artery Disease. 
220 | H KINCHOKU et al.

Table 2. Twenty-four-hour recall of the participants according to gender and age.

\begin{tabular}{lcccc}
\hline Nutrients (\%) & Men $(n=27)$ & Women $(n=24)$ & Adults $(n=44)$ & Elderly $(n=7)$ \\
\hline Calories & $2312 \pm 552$ & $1811 \pm 364^{*}$ & $2151 \pm 520$ & $1600 \pm 343^{\dagger}$ \\
Carbohydrates & $46 \pm 8$ & $46 \pm 8$ & $45 \pm 8$ & $51 \pm 6$ \\
Proteins & $20 \pm 4$ & $18 \pm 4$ & $20 \pm 4$ & $18 \pm 5$ \\
Fats & $33 \pm 9$ & $35 \pm 9$ & $35 \pm 9$ & $31 \pm 9$ \\
Saturated fats & $9 \pm 3$ & $11 \pm 4^{*}$ & $10 \pm 4$ & $11 \pm 5$ \\
Monounsaturated fats & $9 \pm 3$ & $10 \pm 4$ & $9 \pm 3$ & $10 \pm 5$ \\
Polyunsaturated fats & $8 \pm 3$ & $8 \pm 3$ & $8 \pm 3$ & $7 \pm 2$ \\
Cholesterol $(\mathrm{mg})$ & $294 \pm 112$ & $295 \pm 32$ & $281 \pm 113$ & $256 \pm 87$ \\
\hline
\end{tabular}

Note: $p=$ Mann-Whitney; ${ }^{*} p<0.001,{ }^{*} p=0.046$ for gender; ${ }^{\dagger} p=0.009$ for age.

Adults ( $<60$ years) and elderly ( $\geq 60$ years). Data are expressed as means \pm Standard Deviation.

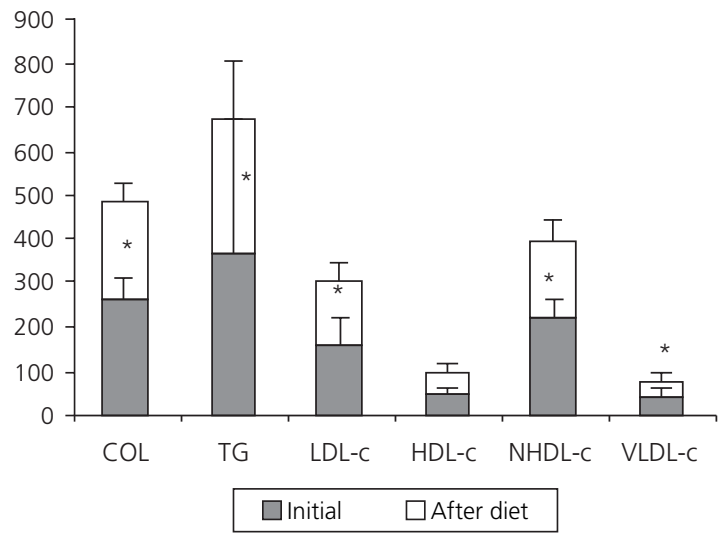

Figure 1. Lipid and lipoprotein profiles at baseline and after nutritional counseling.

Note: C: Cholesterol; TG: Triglycerides; LDL-C: Low Density Lipoprotein-cholesterol; HDL-c: High Density Lipoprotein-cholesterol; VLDL-c: Very Low Density Lipoprotein-cholesterol. NHDL: Non High Density Lipoprotein-cholesterol.

Data are expressed as means \pm Standard Deviation. ${ }^{*} p=$ Wilcoxon adjusted for change in weight (Ancova). C, NHDL-c, TG and VLDL-C $(p<0.001)$; LDL-c $(p<0.02)$.

The TG, LDL-C and HDL-C of this group also improved significantly in response to diet (Figure 2C).

Between the age groups, diet reduced the C, TG and NHDL-C levels of adults by $14 \%, 33 \%$ and $17 \%$, respectively, and reduced the $C$ of the elderly by $14 \%$. In this group, only TG differed in response to diet (Figure 3).

Although most participants lost weight $(4 \%)$, the amount of weight lost was not statistically significant.
DISCUSSION

The present study assessed how the serum lipid and lipoprotein levels of dyslipidemic individuals respond to nutritional counseling by gender and age.

The study participants presented high plasma lipid and lipoprotein levels, and some also presented other risk factors for CHD, such as diabetes (11\%) and hypertension (39\%), which were more prevalent in women (52\%) and in the elderly (69\%).

High protein intake associated with high saturated fat and cholesterol intakes suggest that diet may contribute to the development of dyslipidemia20,21.

The 24 hour recall ${ }^{16}$ used in this study to assess habitual food intake, especially foods and preparations associated with dyslipidemias, was relevant for the nutritional intervention. According to Willett ${ }^{17}$, the semi-quantitative food frequency questionnaire is the main dietary assessment method used in epidemiological studies of disease.

The presence of overweight and obese participants shows the association already described in the literature between excess weight and changes in plasma lipid levels and risk of coronary artery disease ${ }^{22}$.

Visceral obesity was more prevalent in men, indicating their higher risk of developing the metabolic syndrome ${ }^{23}$. 
A

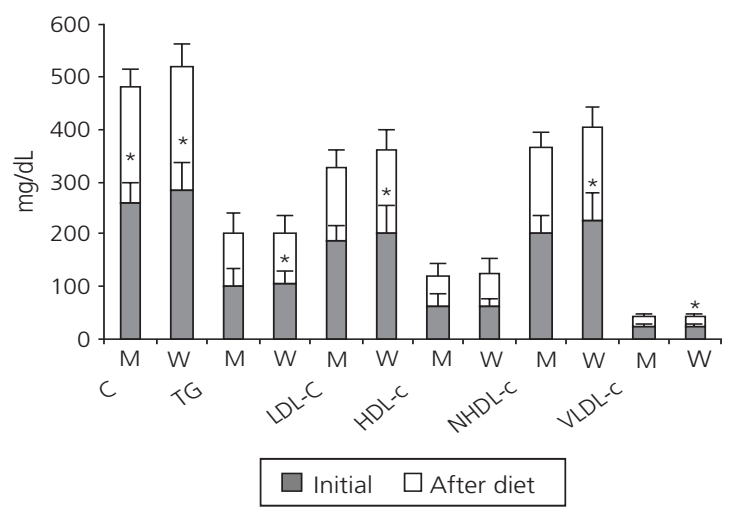

B

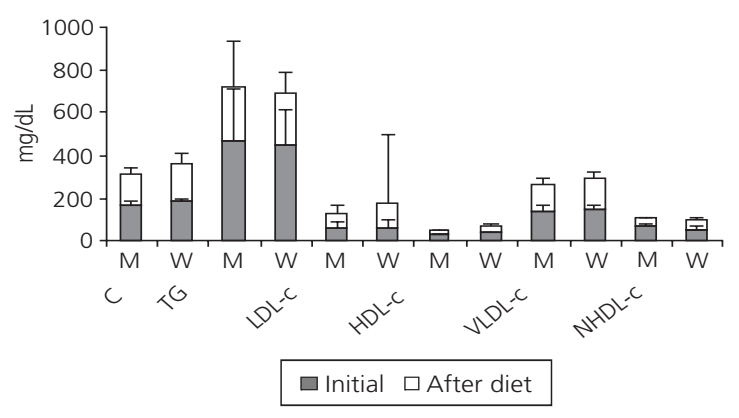

C

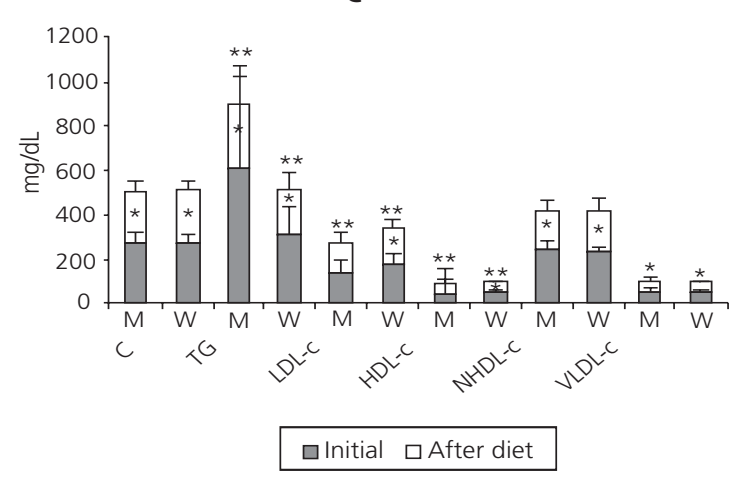

Figure 2. (A) Lipid and lipoprotein profiles at baseline and after nutritional counseling in individuals with hypercholesterolemia by gender. (B) Lipid and lipoproteins profiles at baseline and after nutritional counseling in individuals with hypertriglyceridemia by gender. (C) Lipid and lipoprotein profiles at baseline and after nutritional counseling in individuals with mixed hyperlipidemia by gender.

Note: " $p=$ Wilcoxon adjusted for change in weight (Ancova). C ( $p=0.008)$, LDL-c $(p=0.011)$, NHDL-c (0.016), TG and VLDL-c ( $p<0.001)$ for women; M: Men; and W: Women; C: Cholesterol; TG: Triglycerides; LDL-c: Low Density Lipoprotein-cholesterol; HDL-c: High Density Lipoprotein-cholesterol; VLDL-c: Very Low Density Lipoprotein-cholesterol; NHDL: Non High Density Lipoprotein-cholesterol.

Data are expressed as means \pm Standard Deviations. $C(p=0.04)$ for men. ${ }^{*} p=$ Wilcoxon adjusted for change in weight (Ancova). ${ }^{*} p=$ Wilcoxon adjusted for change in weight (Ancova) C, TG, LDL-c, NHDL for women, and C, TG, NHDL-c ( $p<0.001)$ for men; VLDL-c $(p=0.02)$ in men and $(p=0.006)$ in women ${ }^{* *} p=$ Mann-Whitney for TG $(p=0.004)$, LDL-c $(p=0.02)$, and HDL-c $(p=0.04)$.

The nutritional status of participants according to BMI was: $15 \%$ normal weight, $52 \%$ overweight, $24 \%$ obesity class I, $6 \%$ obesity class II, and 3\% obesity class III. Comparison of the baseline BMI with the BMI at last visit showed a substantial improvement in nutritional profile: normal-weight individuals increased from 15\% to $25 \%$, obesity class I decreased from $24 \%$ to $17 \%$, obesity class II decreased from $6 \%$ to $5 \%$ and obesity class III decreased from $3 \%$ to $1 \%$.
However, the percentage of change in body weight was not statistically significant.

Interestingly, the TG levels of men and adults responded better to diet than those of women and the elderly.

The different TG responses of men and women, adults and the elderly found in this study suggest that the participants who had high baseline TG levels responded better to the low 


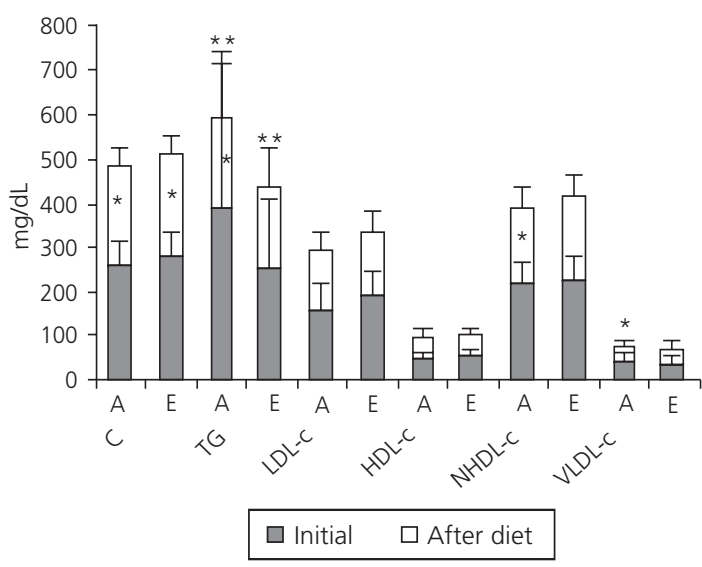

Figure 3. Lipid and lipoprotein profiles at baseline and after nutritional counseling in adults and elderly.

Note: ${ }^{*} p=$ Wilcoxon adjusted for change in weight (Ancova); $C, T G$, VLDL-c, NHDL $(p<0.001)$ for adults and C $(p=0.03)$ for elderly. ${ }^{* *} p=$ Mann-Whitney; TG $(p=0.01)$. $<60$ years (A) and $\geq 60$ year (E); C: Cholesterol; TG: Triglycerides; LDL-c: Low Density Lipoprotein-cholesterol; HDL-C: High Density Lipoprotein-cholesterol; VLDL-c: Very Low Density Lipoprotein-cholesterol. NHDL: Non High Density Lipoproteincholesterol; A: Adults; E: Elderly.

Data are expressed as means \pm Standard Deviation.

fat diet $(<20 \%)$. Similar results were found by Jacobs et al. ${ }^{24}$.

Moreover, the greatest reductions in LDL-c levels were seen in women with mixed hyperlipidemia, suggesting that women might be more sensitive to dietary saturated fat, responding better to $L D L-c$ restriction ${ }^{25}$.

The reductions in $C$ and $L D L-c$ levels achieved by men and women with isolated hypercholesterolemia as a response to diet were similar.

Some studies with individuals with moderate hypercholesterolemia shows that the reduction of LDL-C in response to diet is higher in men than in women ${ }^{10-11}$, whereas other studies show that the reductions in total cholesterol and apolipoprotein B also are higher in men ${ }^{26,27}$. Corroborating this study, some authors found that the reductions in $\mathrm{C}$ and $\mathrm{LDL}-\mathrm{C}$ in response to diet do not differ between genders $8,12,25,28$.

The TG levels of males with mixed hyperlipidemia responded better to diet than those of women. On the other hand, women saw greater reduction in LDL-C. Furthermore, the HDL-C of men in response to diet increased significantly, while that of women decreased.

The decrease in the HDL-c of women in response to diet was also reported by Walden et al..$^{25-29}$ and Yu-Poth et al. ${ }^{30}$.

Changes in lipid and lipoprotein levels were mostly significant, even after adjustment for changes in body weight, highlighting the effectiveness of the dietary intervention used in this study.

The present study has also shown the importance of dietary counseling for patients treated at the outpatient clinic of the university hospital, which achieved a cholesterol reduction of $12 \%$ to $16 \%$, TG reduction of $30 \%$ to $45 \%$ and LDL-C reduction of $15 \%$ to $20 \%$. These responses were greater than the biological variation coefficients for each study parameter $(\mathrm{C}=6 \%, \mathrm{TG}=23 \% \text {, LDL-C }=9.5 \%)^{31}$.

Nutritional counseling proved to be more effective for males and adults, suggesting that new nutritional approach strategies are needed for females and the elderly, including number of follow-up visits, frequency and interval between visits.

Although $30 \%$ of the participants needed to start lipid-lowering drugs, the reductions in lipid levels decreased the number of participants who needed lipid-lowering drugs and the dosages these participants required, resulting in lower health expenses. Therefore, this study reinforces that dietary changes are effective and feasible for the public health system.

Since cardiovascular disease is the leading cause of hospitalization and death, this positive therapeutic procedure should be implemented by other health services in Brazil because it is inexpensive ${ }^{32-34}$ and may help to reduce expenses, and prevent and control CHD.

\section{A C K N OWLEDGEMENTS}

We thank Helymar Machado for the excellent statistical analyses, and the Conselho Nacional de 
Desenvolvimento Científico e Tecnológico and Fundação de Amparo à Pesquisa do Estado de São Paulo for sponsoring the study.

\section{CONTRIBUTORS}

$\mathrm{H}$ KINCHOKU wrote the article as part of thesis dissertation. VS CASTANHO helped with the clinical and laboratory follow-up of the patients and article review. MRG DANELON performed the laboratory analyses. EC FARIA participated in all stages of this study, including article writing.

\section{REFERENCES}

1. American Heart Association. Heart disease and stroke statistics-2012 update: A report from the American Heart Association [cited 2012 Sept 3] Circulation. 2012; 125(1):c2-c220. Available from: <http://circ.ahajournals.org/content/125/22/e1002. full.pdf $>$.

2. World Health Organization. Prevention of cardiovascular disease: Guideline for assessment and management of cardiovascular risk. Geneva: WHO; 2007.

3. Brasil. Ministério da Saúde. Datasus: informações de saúde [acesso em 2012 set 8]. Disponível em: $<$ http://tabnet.datasus.gov.br>.

4. Expert Panel on Detection Evaluation and Treatment of High Blood Cholesterol in Adults. Executive summary of the third report of the National cholesterol Education Program (NCEP) Expert panel on detection, evaluation, and treatment of high blood cholesterol in adults (Adult Treatment Panel III). Jama. 2001; 285(19):2486-97.

5. Lichtenstein $A H$, Appel $L$, Brands $M$, Carnethon M, Daniels S, Franch HA, et al. Diet and lifestyle recommendations Revision 2006: A scientific statement from the American Heart Association Nutrition Committee. Circulation. 2006; 114(1): 82-96.

6. Pejic RN, Lee DT. Hipertriglyceridemia. J Am Board Farm Med. 2006; 19:310-6.

7. IV Diretriz Brasileira Sobre Dislipidemias e Prevenção da Aterosclerose. Arq Bras Cardiol. 2007; 88(Supl 1):2-19.

8. Lichtenstein A, Ausman LM, Jalbert SM, VillellaBach M, Jauhiainen M, McGgloddery, et al. Efiicacy of a therapeutic lifestyle change step 2 diet in moderately hypercholesterolemic middle-aged and elderly female and male subjects. J Lipid Res. 2002; 43:264-73.
9. Denke MA. Review of human studies evaluating individual dietary responsiveness patients with hypercholesterolemia. Am J Clin Nutr. 1995; 62(2):471S-7S.

10. Denke MA. Individual responsiveness to a cholesterol-lowering diet in postmenopausal women with moderate hypercholesterolemia. Arch Intern Med. 1994, 12;154(17):1977-82.

11. Denke MA. Individual responsiveness to a cholesterol-lowering diet in 50 men with moderate hypercholesterolemia. Arch Intern Med. 1994; 154(3):317-25.

12. Jenkins D JA, Kendall C WC, Faulkner D A, Nguyen T, Kemp T, Marchie A, et al. Assessment of the longer-term effects of a dietary portfolio of cholesterol-lowering foods in hypercholesterolemia. Am J Clin Nutr. 2006; 83:582-91.

13. Friedewald WT, Levy RI, Fredrickson DS. Estimation of the concentration of low density lipoprotein cholesterol in plasma, without the use of the preparative ultracentrifuge. Clin Chem. 1972; 18(6):499-502.

14. World Health Organization. Preventing and managing the global epidemic report of a WHO consultation on obesity. Geneva: WHO; 1998.

15. Janssen I, Katzmarzyk PT, Ross Robert. Waist circumference and not body mass index explains obesity related health risk. Am J Clin Nutr. 2004; 79(3):379:84

16. Fisberg RM, Martini LA, Slater B. Inquéritos alimentares: métodos e bases científicos. Barueri: Manole; 2005.

17. Willet WC. Future directions in the development of food-frequency questionnaires. Am J Lin Nutr. 1994; 59(Suppl 1):171S-4S

18. System Nutrition software. NutWin. Version 1.5.2.51. São Paulo: Unifesp; 2006.

19. PI-Sunyer FX. Obesidade. In: Shies ME, Olson JA, Shike $M$, Ross AC, editores. Tratado de nutrição moderna na saúde e na doença. 9a ed. São Paulo: Manole; 2003.

20. Lichtenstein AH. Dietary fat, carbohydrate, and protein: Effects on plasma lipoprotein patterns. J Lipid Res. 2006; 47:1661-7.

21. Damasceno NR, Pérez-Heras A, Serra M, Cofán M, Sala-Vila A, Salas-Salvadó J, et al. Crossover study of diets enriched with virgin olive oil, walnuts or almonds: effects on lipids and other cardiovascular risk markers. Nutr Metab Cardiovasc Dis. 2011; 21(Suppl 1):S14-20.

22. Hamilton M. Strategies for the management of patients with obesity. Treat Endocrinol. 2002; 1(1):21-36. 
23. World Health Organization. Obesity: Preventing and managing the global epidemic. Geneva: WHO; 1998. Report of a WHO Consultation on Obesity.

24. Jacobs B, De Angelis-Schierbaum G, Egert S, Assmann $G$, Kratz M. Individual serum triglyceride responses to high-fat and low-fat diets differ in men with modest and severe hypertriglyceridemia. J Nutr. 2004; 134(6):1400-5.

25. Walden CE, Retzlaff BM, Buck BL, MacCann BS, Knopp RH. Lipoprotein lipid response to the national cholesterol education program step II diet by hypercholesterolemic and combined hyperlipidemic women and men. Arterioscler Thromb Vasc Biol. 1997; 17:375-82.

26. Zhengling Li, Otvos JD, Fava SL, Carrasco WV, Lichtenstein A, McNamara JR, et al. Men and women differ in lipoprotein response to dietary saturated fat and cholesterol restrition. J Nutr. 2003; 133(11):2428-3433.

27. Mensink RP, Zock PL, Kester ADM, Katan MB. Effects of dietary fatty acids and carbohydrates on the ratio of serum total to HDL cholesterol and on serum lipids and apolipoproteins: A meta-analysis of 60 controlled trials. Am J Clin Nutr. 2003; 77(5): 1146-55.

28. Gardner CD, Coulston A, Chatterjee L, Rigby A, Spiller G, Farquhar JW. The effect of a plant-based diet on plasma lipids in hypercholesterolemic adults. Ann Intern Med. 2005; 142:725-33.
29. Walden CE, Retzlaff BM, Buck BL, Wallick S, MacCann BS, Knopp RH. Differential effect of National Cholesterol Education Program Step II Diet on HDL cholesterol, it is sub-fractions, and apolipoprotein A-I levels in hypercholesterolemic women and men after 1 year: The be FIT study. Arterioscler Thromb Vasc Biol. 2000; 20:1580-7.

30. Yu-Poth S, Zhao G, Etherton T, Naglak M, Jonnalagadda S, Etherton PMK. Effects of the National Cholesterol Education Program s Step I and Step II dietary intervention programs on cardiovascular disease risk factors: A meta-analysis. Am J Clin Nur. 1999; 69:632-46.

31. Refai N, Warniek GR, Dominiczaek H, editors. Handbook of lipoprotein testing. $2^{\text {nd }}$ ed. Washington (DC): AACC; 2000.

32. Delahanty LM, Sonnenberg LM, Hayden D, Nathan DM. Clinical and cost outcomes of medical nutrition therapy for hypercholesterolemia: A controlled trial. J Am Diet Assoc. 2001; 101(9):1012-23.

33. Gans KM, Burkholder GJJ, Risica PM, Harrow B, Lasater TM. Cost-effectiveness of minimal contact education strategies for cholesterol change. Ethn Dis. 2006 ; 16:443-51.

34. Repas T. Obesity and dyslipidemia. S D Med. 2011; 64(7):241-3. 